Article

\title{
Achieving Disability Equality: Empowering Disabled People to Take the Lead
}

\author{
Laufey Löve ${ }^{1, *}$, Rannveig Traustadóttir ${ }^{1}$ and James Gordon Rice ${ }^{1,2}$ \\ ${ }^{1}$ Centre for Disability Studies, Faculty of Social and Human Sciences, University of Iceland, 101 Reykjavik, Iceland; \\ E-Mails: lel2@hi.is (L.L.), rannvt@hi.is (R.T.), james@hi.is (J.G.R.) \\ 2 Department of Anthropology, Faculty of Social and Human Sciences, University of Iceland, 101 Reykjavik, Iceland \\ * Corresponding author
}

Submitted: 27 September 2017 | Accepted: 20 December 2017 | Published: 26 March 2018

\begin{abstract}
Achieving disability equality calls for transformative changes to society's structures and norms. Recognizing the central role of disabled people and their organizations in this restructuring, and the call of the Convention on the Rights of Persons with Disabilities (CRPD) for their full inclusion in all legal and policy decisions relating to their rights, this article focuses on how disability groups and organizations regard their ability to effect changes in line with the CRPD. The article draws on qualitative interviews with leaders of disability organizations and activist groups in Iceland in 2016 and 2017. The findings reflect frustration among the leaders with what they perceive to be a lack of sustained progress in the decade since the country signed the CRPD. In their view, this period has been characterized by a lack of meaningful involvement of disabled people in policymaking, and a lack of political will and interest in disability affairs, which has resulted in stagnation. As a result, leaders of disabled people's organizations have begun to change their strategies and are taking steps to redefine their approaches, and reframe the issues and dialogue with authorities in a more progressive manner, demanding to have more say in the process of change.
\end{abstract}

\section{Keywords}

activist groups; CRPD; disabled people; disability equality; empowerment; policymaking; umbrella organizations

\section{Issue}

This article is part of the issue "Disability Equality: In Theory and Practice", edited by Mark Priestley (University of Leeds, UK) and Lisa Waddington (Maastricht University, The Netherlands).

(C) 2018 by the authors; licensee Cogitatio (Lisbon, Portugal). This article is licensed under a Creative Commons Attribution 4.0 International License (CC BY).

\section{Introduction}

Achieving disability equality requires a multipronged approach that includes an accessible physical and social environment that allows disabled people to take full part in society, and where "their needs are understood as integral to the social and economic order and not identified as 'special'" (United Nations, 2010, p. 22). Furthermore, it demands full recognition of the right to autonomy and to make one's own choices (Flynn \& Arstein-Kerslake, 2014; Quinn, 2010). Building on this understanding of what disability equality should at minimum encompass, this article focuses on the need to also embed within its definition an emphasis on the participation of disabled people and their representative organizations in constructing the very policies that are intended to usher in the necessary changes to structures and norms within society to ensure their enjoyment of full human rights.

The importance of the participation of marginalized groups, including disabled people, in policy making has been emphasized within the field of social sciences and human rights law (Charlton, 2000; Guldvik, Askheim, \& Johansen, 2013; Minow, 1990; Oliver, 1990; Priestley et al., 2016; Young, 1990). Recognizing that society's structures and norms are a reflection of existing power relations, created and defined by dominant groups and 
which serve to maintain the status quo, Young (1990) maintains that ridding society of institutionalized domination and oppression is pivotal to achieving justice for marginalized groups. To do so, she argues that it is necessary for marginalized groups to be part of the political structure, setting the agenda, defining the issues and redefining the concepts that relate to their lives. A similar focus on the necessity of leveled and inclusionary participation, parity of participation, is central to Nancy Fraser's theory on justice, which maintains that all members of society should be able to interact with one another as peers (Fraser \& Honneth, 2003). To this end, Fraser highlights the need to uproot both cultural and economic injustices, including norms that have been institutionalized by society and which depreciate some groups of people and undermine their standing as full and equal participants in society (Fraser \& Honneth, 2003). The importance of direct citizen participation in the formulation of political issues is also highlighted in Habermas's theories on the role of the public sphere as a platform for reasoned and critical dialogue. Habermas (1991) describes the public sphere, as it emerged before the increased intertwining of the state and society in the late nineteenth and twentieth centuries, as a forum existing between civil society and the state where critical public discussion could take place among private people, free from outside pressures and where political ideology could be formulated (Habermas, 1991). As such, the public sphere allowed the citizens to develop their agenda before presenting it in the public arena, a format that could be argued as being ideal for giving marginalized groups the necessary breathing space to develop their political agenda. Regrettably, research has shown that even accessing such basic civil rights as the right to cast votes in local, national and-in the case of EU citizens-international elections often poses a challenge for disabled people, resulting in lower voter turnout among them than non-disabled people (European Union Agency for Fundamental Rights, 2010; Priestley et al., 2016; Traustadóttir \& Rice, 2017; United Nations, 2011). This draws attention to the importance of empowering disabled people to participate politically at all levels, as well as to the important role that civil society organizations have in pressuring states into actualizing human rights law (Meyers, 2016).

The Convention on the Rights of Persons with Disabilities (CRPD; United Nations, 2006) embraces this perspective as it firmly recognizes the importance of the participation of disabled people in setting the policies that will affect their lives. It places a positive legal obligation on states parties to seek the input of disabled people and their representative organizations at all levels of development, monitoring, and implementation of disability rights (Sabatello, 2014). These obligations are stated in Article 4(3), which requires states to "closely consult with and actively involve persons with disabilities, including children with disabilities, through their representative organizations," as well as in Article 33(3), which states that persons with disabilities and their representative organizations shall be involved and participate fully in the monitoring process of their rights. Furthermore, Article 34(3)(4) addresses the participation of disabled people, their representative organizations, and experts with disabilities in the interpretation, implementation, and monitoring of the CRPD as members of the monitoring committee.

A participatory emphasis with regard to disability law and regulations has also been increasingly integrated into national legislation and institutional processes, including in Iceland where the law on disability affairs requires consultation with representatives of disability organizations (Law nr. 59/1992, adm. 152/2010) (Althing, 1992). However, as Sherlaw and Hudebine (2015) point out, having incorporated an obligatory consultation with representative organizations of disabled people still leaves unanswered the question of how these policies translate into practice and whether they, in fact, enable disabled people and their representative organizations to affect policy outcomes. To shed light on this question, this article focuses on how leaders of disability organizations and groups in Iceland perceive their effectiveness in influencing disability policy and how they have adapted their approaches in order to strengthen their ability to affect change.

\section{Method}

This article draws on qualitative data comprising interview transcripts. Eleven semi-structured in-depth interviews were conducted with leaders of nine disability groups and organizations in Iceland in 2016 and 2017. The aim was to obtain the leaders' views and experiences with regard to implementing change in line with the CRPD.

Purposeful sampling was used to identify and recruit participants. An effort was made to provide a balanced representation of leaders of both established disability organizations and grassroots and activist groups (hereafter referred to as activist groups). The established organizations this article refers to, including three large umbrella organizations, are comprised of both disabled people and non-disabled people. Their rules vary with regard to whether or not non-disabled members can serve in leadership positions or on their boards. Some of these organizations own and operate services for disabled people and are thus in some cases employers of staff and specialists, as well as being interest organizations. Six interviews were conducted with leaders of established organizations. Of the six leaders, three were disabled and three non-disabled.

Although there are organizational differences among the activist groups discussed in this article, they are all established and run by disabled people, and share the aim of empowering disabled people to lead the fight for achievement of all human rights. Five interviews were conducted with leaders of activist groups; in the case of 
a horizontally organized group, a representative was interviewed. All five were disabled.

The groups and organizations represented varied considerably in how long they had been operational, ranging from less than five years to more than fifty. Membership also varied greatly, with one of the three established umbrella organizations claiming 29 thousand members, whereas some of the activist groups had fewer than 50 . This fact was not considered to be of concern as the focus of the study was predominantly on the ideology behind the methods used to advance disability equality. While the participants differed as to how long they had served as leaders of their organizations, they all had considerable experience in promoting disabled people's rights in various capacities, and all had spoken in public on the issue. Six of the 11 leaders interviewed were women and five were men. Their ages and educational backgrounds varied. All the interviews were conducted in Icelandic and direct quotations translated by the first author of this article. In addition, keeping in mind the small size of the Icelandic population, both names and identifying details have been omitted to the extent possible to ensure confidentiality. All participants gave informed consent and agreed to have the interviews recorded. In one instance, a list of topics to be discussed was provided in advance to give room for preparation.

The article's focus on the perspective of leaders of disabled people's organizations (DPOs) is derived from the belief that disabled people themselves are best positioned to judge whether policies aimed at delivering disability equality have been successful or not, a perspective adopted by Sherlaw and Hudebine (2015), as well as Disability Rights Promotion International (Samson, 2015). To this end, semi-structured interviews were chosen as a method of inquiry to gain knowledge of the subjective understanding, perspectives and meaning that participants attach to the issues. They enable the interviewees to direct the discussion to what they find to be of importance and to express the meaning they attach to concepts, while at the same time allowing the discussion to be directed toward predetermined topics in keeping with the theme of the research (Esterberg, 2002; Taylor, Bogdan, \& DeVault, 2015).

The research employed the grounded theory method, which reflects the premise that theory can be developed from rigorous analysis of empirical data (Charmaz, 2014). In keeping with this approach, the collection and analysis of data was directed by the constant comparative method of grounded theory. This method calls for data gathering to be continued while data is simultaneously coded and analyzed, and analytical memos developed, with the goal of identifying central themes to help direct further data collection and theory building (Charmaz, 2014). To this end, interviews were conducted in three intervals, in December 2016, April 2017 and July 2017, until new information obtained ceased to provide further insight. At the outset, broad questions were posed to leaders of the representative organiza- tions about their approaches to advancing the rights of disabled people. The questions were then narrowed in focus as themes began to emerge from the analysis of the interviews, which were recorded, transcribed and coded. Coding consisted of close reading of the transcripts, followed by sorting and organization of the codes, which were then collapsed into broader categories revealing patterns in the data that helped develop a deeper understanding of the issues at hand (Creswell, 2009).

\section{Findings}

Analysis of the data revealed that the organizations and groups interviewed could be divided into two main categories based on what they perceived to be the most effective way to advance disability equality. On one hand were those who expressed a firm commitment to working in a collaborative manner with the authorities. The cornerstone of their strategy was maintaining an open dialogue and working through negotiations within a framework established by national and local authorities, including committees and other bodies. The established interest organizations generally expressed commitment to this approach. On the other hand, activist groups run by disabled people generally did not give primary focus to collaboration with authorities. Instead, they sought to take the lead in defining the issues of priority concern to their rights and, by so doing, redefining the dialogue to incorporate and reflect their own perceptions and needs. Despite these differences, the organizations also shared some experiences and concerns as outlined below.

\subsection{Collaborative Strategies}

The established organizations expressed a commitment to advancing the rights of disabled people through a process of collaboration with authorities. This approach was described by one of the leaders of the established organizations in the following terms: "We perceive, or I personally, that the authorities are our collaborators, not our adversaries. I don't think we would make any progress if we played that game." Two of the established organizations, both of whom were umbrella organizations, had the right by law to be consulted on issues pertaining to policies concerning disabled people. It should be noted, however, that their appointed representatives are often non-disabled people. While expressing commitment to the collaborative approach, some of the leaders reported feeling as if decisions had at times already been made before meetings called by the authorities were convened. "Sometimes it feels to me as if it's pro forma. They have to include us. And then it's like decisions have already been made at some sort of a pre-meeting" (leader of an established organization). In addition, one leader talked about having to be vigilant to ensure that the comments and opinions expressed by the organization's representative were actually included in the minutes of the meetings. Several of the leaders of established organizations 
also talked about having to dedicate a lot of their time and energy to preventing roll backs of acquired rights. An example cited was a recent directive issued by the Ministry of Welfare that expanded the number of apartments permissible within apartment complexes for disabled people. The leader stated that his organization had opposed this action and pointed out that increasing the number of units was in contradiction to the CRPD. Another example where proposals by representatives of disability organizations were disregarded was the case of a proposed amendment to laws pertaining to facilitating equal access to actualize voting rights (Traustadóttir \& Rice, 2017). The proposed draft legislation did not include the suggested changes by the disability organization and, as a result, did not uphold the intent of the CRPD. This is of concern as the Icelandic disability law (AIthing, 1992) requires that due consideration be given in its execution to international obligations, particularly the CRPD, as stipulated by a 2010 amendment to the law.

Despite frustrations over a lack of progress and feeling that their suggestions and perspectives on issues often went unheeded or overlooked, the leaders of the established organizations expressed a firm commitment to collaboration with the authorities, stating that "we don't see the authorities as our enemies; we see them as our collaborators." Maintaining an open dialogue was a cornerstone of their strategy. "We don't burn bridges," "we don't slam doors," "we are not loud," and "we don't use foul language" were phrases they used to describe their approach to keeping the collaboration and dialogue alive.

Cultivating relationships with politicians, including parliamentarians, government ministers and elected officials at the local level, was regarded by many of the leaders as an important part of the collaborative approach. Two leaders described their approach in this regard as "lobbyism". They talked about actively seeking the attention of individual politicians, through phone calls or personal meetings, with the intent of informing and persuading them to adopt their cause. "You just pick up the phone and call the ones you consider to be likely to speak on behalf of these issues," is how a leader described the process.

Furthermore, a leader pointed out in this context that "we can't use the threat of a strike as part of our negotiating tactics with authorities," making it all the more important, in the leaders' view, to build trust and credibility as negotiating partners. They discussed steps they had taken to strengthen their standing as collaborators and partners, including cultivating a reputation for being trustworthy, calm and professional as opposed to emotional or aggressive. "We have to be much more concerned with our credibility and be a bit careful in what we do," a leader stated. Being able to cite facts in support of their arguments and having relevant research on hand, as well as at times conducting and sponsoring research, was stressed as important in giving their arguments more weight. Among the examples where they felt that collab- oration with authorities had resulted in substantial gains for the rights of disabled people was the process that led to the ratification of the CRPD, where disability organizations reported being heavily involved behind the scenes. However, in general, progress was described as having been slow. Having to accept small steps in the right direction rather than no gain at all was often seen as an unfortunate reality. Expecting full rights to be realized in one step was considered to be unrealistic.

In keeping with their emphasis on collaboration, leaders of the established organizations rejected what they considered to be a more aggressive and confrontational approach employed by some activist groups. Nevertheless, many expressed support and even admiration for the work of these groups, particularly their effectiveness in generating public and media attention. A leader of an established organization did emphasize that rejecting the more aggressive approach did not mean that the leader's organization shied away from bringing up uncomfortable issues in their discussions with the authorities.

While maintaining a commitment to working through a collaborative process, some leaders of the established groups had nevertheless taken deliberate steps to expand on the framework established by authorities. These initiatives, in addition to the lobbying approach, involved inviting politicians to informal discussions where issues that the organization had chosen to highlight were introduced and information material was provided. The intent was to establish personal contact with politicians and direct their focus to issues of prime importance to the organization in the hope that they would adopt them in their political agenda. In this way, the organization attempted to gain a measure of control of the dialogue while still remaining true to the focus of collaboration.

\subsection{Empowering Strategies}

The leaders of activist groups run by disabled people did not prioritize the collaborative approach in the same way as the leaders of the established organizations did. While the methods they employed varied, and some were horizontally organized while others had a more traditional top-down structure, they all had the same key objective: to find ways to take the lead by directing the dialogue to issues they perceived to be fundamental to their interests and to achieving disability rights.

A representative of a horizontally organized activist group identified how the group, through its meetings, provided members with a platform to voice their opinions and preferences, including with regard to which issues should be at the forefront in the fight for rights, and how these issues should be defined and presented to society at large, including the authorities. The group's meetings had an established format with one or two members presenting on a previously agreed upon issue or theme. The presentations were then followed by general discussions where all were encouraged and given an opportu- 
nity to speak their mind. Members of the group reported feeling empowered to voice their views, first within the group and then on occasion in more public fora. This format gave the group the time and space to define issues in terms that reflected their perceptions and needs. In essence, it allowed for the redefinition of issues from a new perspective where members of the group maintained full control. A person associated with the group pointed out that "the needs of disabled people have until now traditionally been left to 'experts' to define. Now, disabled people are defining the issues themselves. This gives voice to people who are not used to having a voice." By adopting this method, members of the group were able to identify as leaders of the process and as the ones in control.

A leader of another activist group run by disabled people described a similar platform for dialogue where members took turns leading the discussion at the group's meetings and where everybody present had an opportunity to raise issues of concern to them. "This is meant to be a platform for all, that is all our members, to have a say." Through this process, the group brought issues that members wanted to focus on to the forefront. This allowed the issues to reflect the perspectives and lived experiences of the group members and then, on occasion, to be presented as such to authorities and the larger public.

The methods that these two groups employed were focused on empowering disabled people to take the lead in defining the issues and the methods used to ensure the full attainment and recognition of their rights. In both instances, the definition of the issues occurred through dialogue and peer-led discussions that took their cues from the perspectives and lived experiences of disabled people themselves.

Another strategy used by the activist groups was the initiative that one of the groups took to draft a legislative proposal to present to the authorities. By so doing, the group felt that it was both breathing life into a stalled process and taking the lead in defining the issues under discussion, with the aim of influencing the outcome. The proposed text emphasized what the group felt needed to be discussed or acted upon. The intent, as in the previous two cases, was to take charge of how the rights of disabled people were stated and defined, and, in this way, affect policy outcomes. Furthermore, the leader of the group felt that taking the lead in drafting the proposed legislation provided a measuring stick that would help evaluate the outcome document. "If other draft legislation is presented that is very much different to ours, then they [members of parliament] will at least know that it is not in line with our ideas and we can then point to that."

The methods employed by the activist groups at times reflected a sense of urgency. One leader described how members wore chains around their necks in public as a form of protest against obstacles to relocating for persons with disabilities. Another group described taking to the streets in demonstration, delivering declarations to the authorities. In one instance, a parade was organized to demonstrate the members' pride as a form of self-advocacy. Other methods included writing and publishing first person accounts of the lived realities of disabled people and the hindrances they face on a regular basis. The public demonstrations were described by the leaders as being intended to bring visibility to the fight for disability equality and to enhance public understanding of the issue. "We do this to bring attention to where there are cracks in the system and where the system needs to do better....The point is to open people's eyes to the lives of disabled people," said one leader. However, the representatives interviewed maintained that being aggressive or shocking was not in itself a deliberate strategy. Members of the activist groups described their methods as a way of opening people's eyes to the lived reality of disabled people in Iceland in the hope of sparking a wider public dialogue and gaining more control of the image presented publicly of disabled people. This approach was intended to allow disabled people to take control of the dialogue and to claim the role of experts of their own lives, and on disability in general, a role that has traditionally been occupied exclusively by others.

\subsection{Shared Experiences and Concerns}

Although the leaders of DPOs and activist groups in Iceland differed with regard to which approach they focused primarily on in advancing disability equality, they nevertheless shared many experiences and concerns regarding the implementation of changes in line with the CRPD.

First and foremost, they all expressed frustration over the lack of progress in achieving full recognition of the rights of disabled people, despite the fact that the government had signed the CRPD in 2007, passed an amendment to the existing disability law in 2010 requiring compliance with the CRPD, and finally ratified the Convention in 2016. The greatest hurdles to progress, in their view, included a lack of political will, particularly the will to dedicate resources to actualizing the rights of disabled people, and a lack of interest in and understanding of the lived realities of disabled people. "I just think it's laughable," one leader said. "The authorities just have to come to terms with the fact that it [securing human rights] is going to cost money." With regard to their engagement with authorities, they expressed frustration over not being heard in the sense that their comments, suggestions and opinions on matters were often not heeded and did not find their way into policies. This was also the case with the two organizations that Icelandic authorities are legally obligated to consult with in the development of policies.

The leaders also all voiced the importance of emphasizing the rights of disabled people as human rights and of referring to the CRPD in their dealings with authorities. Generating media attention to increase pressure was a strategy employed by all to some degree. All emphasized the need to adopt the CRPD into national law as an im- 
portant step toward actualizing rights. Furthermore, the lack of progress led a number of leaders to express a desire to increase the use of legal avenues, that is pursuing rights through the court system to force authorities to bring about disability equality.

\section{Discussion}

From the perspective of disability equality as defined at the outset of this article, it is a cause for concern that the leaders of DPOs report having difficulty being heard by the authorities. Their experience was that meetings called by authorities were at times perceived to be pro forma, that sometimes it seemed as if decisions had already been made and that they even had to remain vigilant to ensure that their comments were included in the minutes of the meetings. These concerns point to a problem in actualizing the active and participatory role of disabled people called for by the CRPD. The CRPD is clear in this regard as it places a positive obligation on states parties to seek the input of disabled people and their representative organizations at all levels of development, monitoring and implementation of disability rights (Sabatello, 2014). It leaves no doubt, as Kumpuvuori and Virtanen (2017) point out, that DPOs can no longer be excluded in processes that concern them. However, in practice, the extent to which these obligations are met varies. On the one hand, there is what Kumpuvuori and Virtanen term "illusionary" participation, where there is, in fact, no real opportunity to affect the outcome of the decision-making process, either due to a lack of knowledge and skills by the DPOs or as a result of the DPOs only being brought in at the latter stages of the process. They also identify as "illusionary" participation when an opportunity to state an opinion is given but the opinion expressed is not taken into account. On the other hand, there is full participation where DPOs are a part of the decision making "in an effective manner, from the beginning to the end of the process" (Kumpuvuori \& Virtanen, 2017, p. 59).

The experience of the Icelandic disability groups and organizations seems to suggest that there are still barriers to their full and effective participation in the policymaking process and with regard to their ability to effect policy outcomes and promote disability equality. The existing structure of collaboration with the authorities includes a participatory process that retains some similarities to what Kumpuvuori and Virtanen identify as "illusionary" participation rather than full participation. The result has been frustration with the pace of progress, which has led the activist groups to develop more empowering strategies that, in essence, aim at establishing disabled people as leaders of the fight for their rights. While maintaining a firm commitment to the collaborative process, the perceived lack of progress has also led the established organizations to seek ways to gain more control of the dialogue. Furthermore, leaders from both the established organizations and activist groups have expressed a desire to focus more on pursuing disability rights through the courts as a way of forcing the authorities to take action.

The findings presented in this article, particularly with regard to the activist groups, find support in Young's (1990) theories and her conclusion that to effect fundamental change it is necessary for marginalized groups to be engaged in redefining the underlying structures and norms that maintain their marginalization. This perspective is echoed by Fraser, who argues that without the uprooting of norms that have been institutionalized by society, the full and equal participation of depreciated groups such as disabled people cannot be realized (Fraser \& Honneth, 2003). It should be noted that problems in actualizing the effective participation of disabled people and their representative organizations in the policy making process without instituting structural changes have been recognized in other national contexts, including the Bulgarian (Mladenov, 2009). The approach employed by the Icelandic activist groups aligns with Young's and Fraser's theories. The activist groups who, unlike the established organizations that are represented exclusively by disabled people, have taken on this task by attempting to assert disabled people themselves as the leaders of the process of achieving disability equality. They do this by empowering their members to redefine, from their own perspectives and based on their lived experiences and expertise, the issues that are at the heart of the pursuit of disability equality. Only by restating the issues from their perspectives, and thus redefining the dialogue, can disabled people ensure that their interests and preferences are fully reflected in the construction of the policies that are intended to usher in the changes to the norms and structures that have served to maintain their marginalization. Furthermore, the DPOs, particularly those represented by disabled people, provide a platform that gives visibility and validity to the perspectives of disabled people, and an avenue for their integration into policies that affect the lives of disabled people.

Interestingly, there are some similarities between the methods adopted by one of the activist groups and Habermas's theories on the public sphere as a platform for reasoned dialogue on political issues. The group has created an arena for critical dialogue among its members that is both structured in nature and, at the same time, protected from outside pressure. It brings together elements that Habermas considered ideal for developing political ideology, which could then be taken up within the public arena.

These methods have proven to be effective as they have enabled the group to develop the means of stating, and then presenting, its perspective on various disability issues.

At the outset, the article drew attention to the importance of embedding within the definition of disability equality an emphasis on the participation of disabled people and their representative organizations in constructing the very policies intended to usher in the nec- 
essary changes in society to ensure their enjoyment of full human rights. To this end, the article has drawn on writings that argue that to remove barriers to full participation it is necessary to redefine existing structures and norms and to ensure the inclusion of affected groups in the process. With these arguments in mind, and the experience of the Icelandic disability groups and organizations, the importance of States Parties embracing the CRPD's participatory requirements, by fully implementing measures to ensure the direct and active involvement of disabled people, is evident. As Sherlaw and Hudebine (2015) and Kumpuvuori and Virtanen (2017) point out, the membership of committees established by authorities to consult on new legislation and policies often does not give prominence to the voices of disabled people and their representative organizations. Sherlaw and Hudebine point to the French case where the established organizations appoint one third of the membership of consultative committees. In the Icelandic case, representatives of disabled people counted for only one sixth of the members of a working group established by the Minister of Social and Housing Affairs to review existing law on disability services (Althing, 2017). The only disabled member of the group resigned, leaving only non-disabled representatives from DPOs. In addition, one of the two organizations that appoint representatives to the committee owns and operates services for disabled people and, as such, is also an employer of staff, which complicates, at times, its ability to serve as a representative of disabled people's interests (Sherlaw \& Hudebine, 2015). The issue of representation was raised by the disability community during the drafting of the CRPD, which was marked by the extensive involvement of civil society organizations (Samson, 2015; Stein \& Lord, 2010). One of the suggestions put forth called for the Convention to stipulate that all members of the CRPD Monitoring Committee be disabled persons and another that the chair of the CRPD Committee be a disabled person (Stein \& Lord, 2010). The intent of these suggestions was to give prominence to the lived experiences of disabled people. While these suggestions were not adopted, they nevertheless serve to direct the focus to the importance of ensuring that disabled people be in a leading position in defining the rights and policies that pertain to them. This position is embodied in the disability movement's slogan, "nothing about us without us", which makes implicit reference to the longstanding denial of disabled people's right to make decisions on matters that pertain to their lives (Samson, 2015).

\section{Conclusion}

The limited ability of disability groups and organizations in Iceland to effect legislation and policy that relate to their lives has led activist groups to develop new approaches that aim to empower disabled people and assert them as the leaders of the process of achieving full rights. The more recently formed activist groups have de- veloped strategies that have enabled them to define and redefine issues that pertain to their needs and their lives, based on their own perceptions, and to present them as such in the public arena. This allows disabled people to emerge as leaders and experts in their own affairs. This article has argued that the direct involvement of disabled people in changing society's norms and structures that have served to marginalize them is necessary to effect real change and, therefore, achieve disability equality.

\section{Acknowledgments}

The authors would like to express their sincere appreciation to the leaders of disability groups and organizations in Iceland who agreed to be interviewed for this study.

\section{Conflict of Interest}

The authors declare no conflict of interests.

\section{References}

Althing. (1992). Lög um málefni fatlađs fólks. (Disability Law No 59/1992.) Reykjavik: Althing.

Althing. (2017). Frumvarp til laga um pjónustu við fatlađ fólk međ miklar stuđningsparfir. (Draft legislation pertaining to services for disabled people with significant support needs, Parliamentary document No 571438.) Reykjavik: Althing.

Charlton, J. I. (2000). Nothing about us without us: Disability oppression and empowerment. Berkeley: University of California Press.

Charmaz, K. (2014). Constructing grounded theory (2nd ed.). Thousand Oaks: Sage.

Creswell, J. W. (2009). Research design: Qualitative, quantitative, and mixed methods approaches (3rd ed.). Thousand Oaks: Sage.

Esterberg, K. G. (2002). Qualitative methods in social research. Boston: McGraw Hill.

European Union Agency for Fundamental Rights. (2010). The right to political participation of persons with mental health problems and persons with intellectual disabilities. Vienna: European Union Agency for Fundamental Rights.

Flynn, E., \& Arstein-Kerslake, A. (2014). Legislating personhood: Realizing the right to support in exercising legal capacity. International Journal of Law in Context, 10(1), 81-104.

Fraser, N., \& Honneth, A. (2003). Redistribution or recognition? A political-philosophical exchange. London: Verso.

Guldvik, I., Askheim, O. P., \& Johansen, V. (2013). Political citizenship and local political participation for disabled people. Citizenship Studies, 17(1), 76-91.

Habermas, J. (1991). The structural transformation of the public sphere: An inquiry into a category of bourgeois society. Cambridge: The MIT Press.

Kumpuvuori, J., \& Virtanen, R. (2017). Are we right or 
are we right? 'Right approach' in the advocacy work of organisations of persons with disabilities. In C. O'Mahony \& G. Quinn (Eds.), Disability law and policy: An analysis of the UN Convention (pp. 55-65). Dublin: Clarus Press.

Meyers, S. (2016). NGO-Ization and human rights law: The CRPD's civil society mandate. Laws, 5, 21.

Minow, M. (1990). Making all the difference: Inclusion, exclusion and American law. Ithaca: Cornell University Press.

Mladenov, T. (2009). Institutional woes of participation: Bulgarian disabled people's organisations and policymaking. Disability \& Society, 24, 33-45.

Oliver, M. (1990). The politics of disablement: Critical texts in social work and the welfare state. London: Macmillan.

Priestley, M., Stickings, M., Loja, E., Grammenos, S., Lawson, A., Waddington, L., \& Fridriksdóttir, B. (2016). The political participation of disabled people in Europe: Rights, accessibility and representation. Electoral Studies, 42, 1-9.

Quinn, G. (2010). Personhood \& legal capacity: Perspectives on the paradigm shift of article 12 CRPD. Paper presented at the HPOD Conference, Harvard Law School, Boston.

Sabatello, M. (2014). A short history of the international disability rights movement. In $\mathrm{M}$. Sabatello \& $\mathrm{M}$. Schulze (Eds.), Human rights and disability advocacy (pp. 13-24). Philadelphia: University of Pennsylvania Press.

Samson, R. M. (2015). Securing the full participation of persons with disabilities and their representative organizations in disability rights monitoring. In M. H. Ri- oux, P. C. Pinto, \& G. Parekh (Eds.), Disability, rights monitoring, and social change: Building power out of evidence. Toronto: Canadian Scholars Press.

Sherlaw, W., \& Hudebine, H. (2015). The United Nations Convention on the Rights of Persons with Disabilities: Opportunities and tensions within the social inclusion and participation of persons with disabilities. $A L-$ TER, European Journal of Disability Research, 9, 9-21.

Stein, M. A., \& Lord, J. E. (2010). Monitoring the Convention on the Rights of Persons with Disabilities: Innovations, lost opportunities, and future potential. $\mathrm{Hu}$ man Rights Quarterly, 32(3), 689-728.

Taylor, S. J., Bogdan, R., \& DeVault, M. L. (2015). Introduction to qualitative research methods: A guidebook and resource (4th ed.). New York: John Wiley \& Sons.

Traustadóttir, R., \& Rice, J. G. (2017). Kosningar, lýđræði og fatlað fólk (Elections, democracy and disabled people). Icelandic Review of Politics \& Administration, 13(1), 83-102.

United Nations. (2006). The Convention on the Rights of Persons with Disabilities and Optional Protocol. New York: United Nations.

United Nations. (2010). Monitoring the Convention on the Rights of Persons with Disabilities: Guidance for human rights monitors (Professional training series No. 17). New York and Geneva: United Nations.

United Nations. (2011). Thematic study by the Office of the United Nations High Commissioner for Human Rights on Participation in Political and Public Life by Persons with Disabilities. (A/HRC/19/36). New York: United Nations.

Young, I. M. (1990). Justice and the politics of difference. New Jersey: Princeton University Press.

\section{About the Authors}
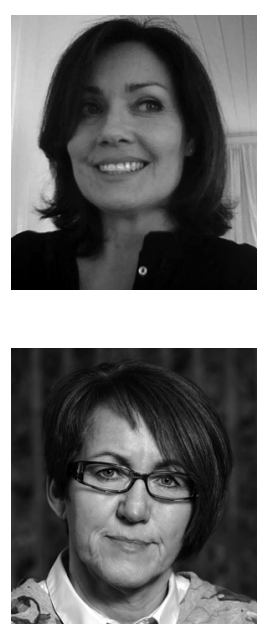

Rannveig Traustadóttir is Professor in Disability Studies and Director of the Centre for Disability Studies, Faculty of Social and Human Sciences, University of Iceland. Much of her research has examined the intersection of disability and other categories of inequality. Her current research focuses on violence against disabled women, independent living and personal assistance, and how the UN Convention on the Rights of Persons with Disabilities can be used to promote full human rights and equality for disabled people.

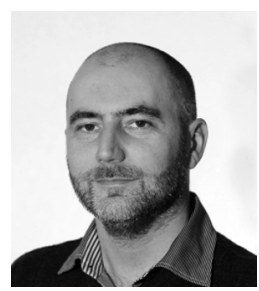

James G. Rice is an Assistant Professor of Anthropology at the Faculty of Social and Human Sciences and a member of the Centre for Disability Studies, both at the University of Iceland. His has recently published on issues of disability in Laws, the Icelandic Review of Politics and Administration, Journal of Applied Research in Intellectual Disabilities and a chapter in the edited volume Disability and Rurality (Routledge). 